\title{
Towards a Reflective Approach to Research Project Management
}

\author{
Lorène Prost, Marie Chizallet, Marie Taverne, and Flore Barcellini
}

\begin{abstract}
This chapter describes how we supported the project leaders of TATABOX in their task of designing a management system for the project. We did so by fuelling their reflectivity: rather than making suggestions on how to manage the project - in a normative approach -, we analysed the on-going project management and mirrored what had been done after a year. The TATA-BOX project leaders would thus be able to decide how to adjust their management and to carry on - in a reflective approach. We report on this process in this chapter: after giving some theoretical background on the concept of reflectivity and its role in helping the project leaders to manage TATA-BOX, we describe: (1) how we worked with them over 6 months, 1 year after the project began, and (2) the different methods we used to meet the project leaders' expectations. We then discuss the efficiency of these methods, their effects on the management of the project, and some lessons learned for the management of such research projects generally.
\end{abstract}

L. Prost $(\bowtie)$

LISIS, INRA, EPNC, ESIEE, Université Paris-Est Marne La Vallée, Marne La Vallée, France e-mail: lorene.prost@inra.fr

M. Chizallet $(\bowtie)$

LISIS, INRA, EPNC, ESIEE, Université Paris-Est Marne La Vallée, Marne La Vallée, France

CRTD, CNAM, Paris, France

e-mail: marie.chizallet@cnam.fr

M. Taverne

Territoires, Université Clermont Auvergne, AgroParisTech, INRA, Irstea, VetAgro Sup,

Aubière, France

e-mail: marie.taverne@ irstea.fr

F. Barcellini

CRTD, CNAM, Paris, France

e-mail: flore.barcellini@cnam.fr

(C) The Author(s) 2019

J.-E. Bergez et al. (eds.), Agroecological Transitions: From Theory to Practice in Local Participatory Design, https://doi.org/10.1007/978-3-030-01953-2_10 


\section{Introduction}

For scholars interested in design studies, the TATA-BOX project (cf. Chap. 2) is like a concentrate: it intertwines three design processes, each of which can be studied individually. The first design process was the initial focus of the project: designing local agroecological transitions (AET). Acknowledging the nature and stakes of agroecological forms of agriculture, the researchers in the TATA-BOX project then felt that this design process should be conducted by the local stakeholders themselves. The project was therefore aimed at designing a methodology to support local stakeholders in designing their AETs. This was the second design process. The course of the project was devoted to proposing such a methodology to local actors, and to implementing its different steps with them. The idea was to iteratively adapt the methodology in order to continue its design into use (Béguin 2003) in an adaptive way. In fact, the initiators of the project had quickly established that biodiversitybased agriculture required farmers to deal with complexity and uncertainty in a process-oriented and goal-seeking approach (Duru et al. 2015). Organising a transition towards this form of agriculture consequently had to rely on specific bases, that is, on an adaptive and participatory approach. But the question was how to organise a project to achieve such a process? This was where the third design process came into play: designing a management system that would support the project. How could the TATA-BOX project leaders design the management of a project that was intended to design a method to support the design of a local AET?

As it was funded by the French National Research Agency, TATA-BOX was structured as a typical project, that is, with "the accomplishment of a clearly defined goal in a specified period of time, within budget and quality requirements" (Lenfle 2008), with work packages, milestones and deliverables. But its project leaders had claimed from the very beginning that what applied to the design process of AETs should also apply to the project itself. They wanted the project to be "participatory, collective, evolutionary, adaptive and adhocratic" (Chizallet 2015). This placed the project leaders of TATA-BOX in a very particular management position, in between project management and adaptive management (Holling 1978; Walters 1986), for they had to design their own management for the project.

This chapter describes how we endeavoured to support the project leaders of TATA-BOX in their task of building what we have called the third design process, that is, their design of a management system for the project. We proposed to do so by fuelling their reflectivity: rather than making suggestions on how to manage the project - in a normative approach -, we would analyse the on-going project management and mirror what had been done after a year. The TATA-BOX project leaders would thus be able to decide how to adjust their management and to carry on - in a reflective approach. We report on this process in this chapter.

After giving some theoretical background on the concept of reflectivity and its role in helping the project leaders to manage TATA-BOX, we describe: (1) how we worked with them over 6 months, 1 year after the project began, and (2) the different 
methods we used to meet the project leaders' expectations. We then discuss the efficiency of these methods, their effects on the management of the project, and some lessons learned for the management of such research projects generally.

\section{Theoretical Positioning}

We grounded our work in the Activity-Centred Ergonomics approach to activity, design and design process management (Daniellou and Rabardel 2005; Barcellini et al. 2014). Over the past 30 years, activity ergonomics has developed an approach to support design projects that aims to foster better interactions between project stakeholders, better integration of existing activity, and anticipation of future activity: in our case, the activity of project management. This approach acknowledges that: (1) there is often a lack of strategic management of projects, that is, not only of coordination issues but of actual management (e.g. strategic decision making); and (2) the structure of the project itself is often at fault, with a focus on the technical dimensions of the project to the detriment of the aspects related to the work of those impacted by the project, and the organisation of work and training. We were therefore interested in the project leaders' intent in TATA-BOX: based on their understanding of the design processes of a transition towards agroecology, they wanted the project management to be "participatory, collective, evolutionary, adaptive and adhocratic". In view of this position, we decided to support them by not giving them immediate design management solutions, especially since activity ergonomists have always pleaded for specific, adequate and localised interventions adjusted to the partners' demand and to their actual activities (Daniellou 1992; Guérin et al. 2006). We moreover wanted to build an intervention that would support the project leaders' learning about their activity. Activity-centred ergonomics has revealed that every work activity comprises a productive dimension directed at performing the task, and a constructive dimension that transforms workers' skills and organisation (Samurçay and Rabardel 2004). We intended to develop this constructive dimension of the project leaders' activity. Accordingly, and due to the investigative nature of the management that they wanted to explore, we chose to place them in a position to reflect upon their own project management, in other words, to be "reflective practitioners" (Schön 1983).

In this respect, Activity-Centred Ergonomics has proposed methodologies to foster the constructive dimension of work by engaging workers collectively in a reflective activity. This implies "a critical analysis of the activity, either to compare it to a prescriptive model, to what one should or could have done differently, and to what another practitioner might have done, or to explain and critique it" (Perrenoud 2001: our translation). This critical analysis may support the construction of "new" knowledge about work activity and related skills (Teiger and Falzon 1995). Collective reflective activity aims at learning from experience and "switching from 
knowledge in action to knowledge of action" (Mollo and Nascimento 2014: 208). Supporting a reflective activity implies helping participants to build reflection on past actions (Mollo and Nascimento 2014) through "a social, language-based and intra-/inter-subjective activity based on actual experience" (Le Goff 2014: 3, our translation). This particular activity must be fed by a representation of actions performed by participants, that is, what they actually did and not what they planned or intended to do (Mollo and Nascimento 2014). On the basis of the "critical analysis"of their own activity, participants may: learn about their own experience and thus develop meta-understanding about themselves and their capacity for action (Teiger and Falzon 1995), and may enhance their potential to act, and their adaptive skills. The setting built to enhance this reflective activity is of prime importance. One of its main characteristics is its anchorage in the intermediary objects (Vinck 2009, 2011) that represent actual activity - in our case, project management activity. Another characteristic is the need for interpersonal mediation as essential to the performance of reflective activity (Perrenoud 2001; Petit et al. 2007; Chaubet 2010).

The reflective intervention that we proposed was clearly inspired by activitycentred ergonomics and had two objectives. The first was to allow the project leaders to learn about their project management activity and to improve it if necessary, in order to achieve their own goals. Our second objective was to show the project leaders how to build some reflective areas by themselves, for the project people, in order to support their intention to manage their project in a "participatory, collective, evolutionary, adaptive and adhocratic" way. In fact, to support their idea of adaptive management, we had assumed that specific management tools inspired from reflective tools would be needed to adapt the course of the project over time.

\section{Material and Methods}

\section{Construction of a First Diagnosis}

Our intervention began in October 2014, 9 months after the beginning of the project. In line with the principles of ergonomics, the intervention began with an analysis of the project management and a reformulation of the project leaders' expectations. The project leaders were the two researchers who had designed most of the project: the official project leader, called "scientific coordinator", in charge of its strategic management, and a research engineer in charge of the project's coordination.

This first step involved six semi-structured interviews with the three project leaders and three researchers involved in the project. The objective of these interviews was to collect the project leaders' and researchers' representation of the project. All these interviews were recorded and transcribed. To complete them, an activity ergonomist carried out so-called "global observations" (Guérin et al. 2006) in the same office as one of the project leaders. These observations were intended to opportunistically capture real-world project issues such as gaps between project leaders' representations and actual actions, regulations performed by the project 
leaders to cope with unexpected events during the project, and so on. She also sat in on three project meetings (one involving the three project leaders, one involving two project leaders, and one involving researchers and the three project leaders). Finally, the ergonomist performed an analysis of documents related to the project (TATABOX project proposal, main publication of researchers, such as Duru et al. 2014, 2015) to reveal the project leaders' initial representations of the project: the stakes (economic stakes, production stakes, stakes related to work activity), whether these were made explicit or not, and the project structure that had been implemented.

\section{Reflective Intervention: An Exploratory Building Process}

The diagnosis described in Section "Construction of a first diagnosis" was the first input to begin the reflective intervention with the project leaders. The set-up of this intervention was then iteratively built from one meeting to the next according to the outcomes of the meeting and the development of the project leaders' thinking about their project management.

\section{Global Framework of the Intervention}

A first meeting called "Intervention Proposal"was organised (January 2015) between the TATA-BOX project leaders and the members of the "Reflectivity Group" (RG; the four authors of this chapter). During this meeting, the first modalities for the implementation of reflectivity were established. The following were agreed: the time to develop a reflexive activity (a two-hour reflectivity meeting would be convened once a month), the space (which office), the roles (the TATABOX project leaders would be the reflective practitioners, the reflectivity group $\mathrm{RG}$ - would be in charge of the facilitation). All the participants also agreed on the idea of adapting the next meetings based on discussions, reactions and requests of the current meeting. Finally, they agreed that, for each meeting, a time of contribution by the RG would be coupled with a participatory exercise at the end of the meeting. The exercises would be proposed by the RG to the practitioners in order to encourage the emergence and evolution of their reflective activity. These workshops would place the project leaders in a reflective exercise on a particular aspect of the project or its organisation. They would encourage discussions among practitioners with a sharp reduction in the facilitator's intervention.

\section{Description of the Reflective Intervention}

After this first meeting, the construction of the intervention was carried out in an exploratory way during a series of four RG meetings that consisted of: (1) determination of objectives for the meeting; (2) search for research material to feed the 
meeting and achieve its objectives (theoretical frameworks, researchers' activities, project elements, etc.); (3) preparation of the facilitation of the meetings (slideshows, exercises); (4) the meeting itself; (5) assessment at the end of the meeting with the TATA-BOX project leaders and the RG; (6) debriefing of the meeting within the RG and analysis; and (7) determining new objectives for the next meeting based on these analyses.

This led to the design of the reflective intervention described in Fig. 1. All these meetings were held with the project leaders. Table 1 provides details about the goal of each meeting, the inputs that were used to build and lead the meetings, and the exercises that were done with the project leaders.

Some objectives of the intervention required the extension of the initial diagnosis to an analysis of on-going events of the project. That was particularly the case of Meeting 3: "Feedback on methodological seminar". During this meeting, the RG decided to focus on a specific seminar that had been organised a few months earlier, and during which all the TATA-BOX researchers had been asked to design the organisation of the project. Feedback about this seminar was drafted by the RG based on:

- An analysis of written and audio tracks of the seminar: initial intentions of project leaders, actual object discussed during the seminar.

- Seven semi-structured interviews with participants at the seminar. The interviews took place 8 months after the seminar. The duration was $1 \mathrm{~h}$ each. A reminder of the seminar programme was read by the ergonomist to the researcher interviewed at the beginning of the interview.

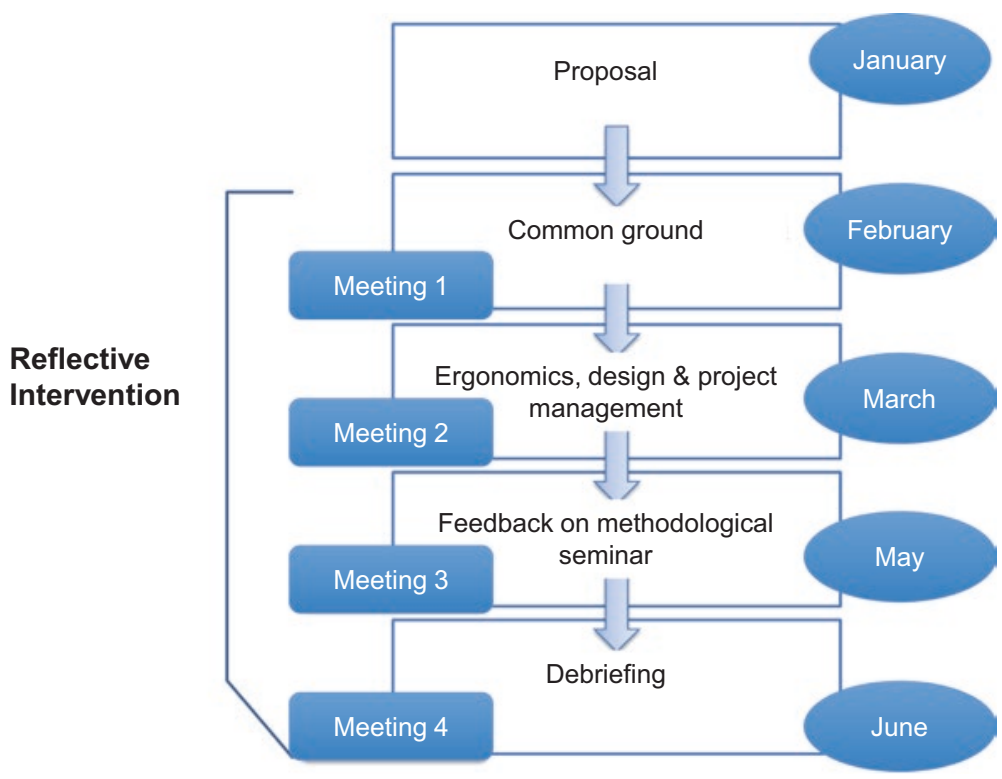

Fig. 1 Synthetic view of the reflective intervention 
Table 1 Goals, inputs and methods used during the reflective interventions

\begin{tabular}{|c|c|c|c|}
\hline & Goals & $\begin{array}{l}\text { Inputs presented by } \\
\text { the ergonomist }\end{array}$ & Participatory exercises \\
\hline $\begin{array}{l}\text { Meeting } \\
1 \text { - February } 15 \\
\text { Building a } \\
\text { common } \\
\text { ground }\end{array}$ & $\begin{array}{l}\text { Provide an external } \\
\text { vision of the project and } \\
\text { share a common vision. } \\
\text { Discuss the objectives of } \\
\text { the project and its } \\
\text { difficulties. Define the } \\
\text { roles of the project } \\
\text { leaders and distribute } \\
\text { them. }\end{array}$ & $\begin{array}{l}\text { Diagnosis built by } \\
\text { the ergonomist }\end{array}$ & $\begin{array}{l}\text { Role sharing } \\
\text { Instructions: Please, ask } \\
\text { yourself: What does this } \\
\text { role, or this task, entail? } \\
\text { Who carries out this task? } \\
\text { Material: Four sheets of } \\
\text { different colours, one for } \\
\text { each of the three researchers } \\
\text { of the nucleus, a fourth for } \\
\text { the other researchers of the } \\
\text { project. A list of roles and } \\
\text { tasks on labels: Some } \\
\text { reported from interviews, } \\
\text { others added by the } \\
\text { ergonomist. Other blank } \\
\text { labels are available for other } \\
\text { roles or tasks that do not } \\
\text { appear here, and to multiply } \\
\text { certain roles or tasks that } \\
\text { would be distributed to } \\
\text { several researchers. }\end{array}$ \\
\hline $\begin{array}{l}\text { Meeting } \\
2-\text { march } 15 \\
\text { Ergonomics, } \\
\text { design and } \\
\text { project } \\
\text { management }\end{array}$ & $\begin{array}{l}\text { Bring in concepts of } \\
\text { ergonomics. Build links } \\
\text { between the concepts } \\
\text { proposed by the } \\
\text { ergonomist and the } \\
\text { project. Reflect together } \\
\text { on what a collective and } \\
\text { participatory conception } \\
\text { implies. } \\
\text { Examine together the } \\
\text { characteristics of the } \\
\text { project: Adhocratic, } \\
\text { participative and } \\
\text { collective project. }\end{array}$ & $\begin{array}{l}\text { Bibliographic search } \\
\text { on collective design, } \\
\text { participatory design, } \\
\text { project management, } \\
\text { adhocracy } \\
\text { Diagnosis built by } \\
\text { the ergonomist }\end{array}$ & $\begin{array}{l}\text { Appropriation } \\
\text { Instructions: Please explain } \\
\text { how you would apply the } \\
\text { general concepts brought by } \\
\text { the ergonomist to } \\
\text { TATA-BOX. } \\
\text { Material: Each slide } \\
\text { presented by the ergonomist } \\
\text { had to be taken up by the } \\
\text { project leaders and adapted } \\
\text { to the specific case of the } \\
\text { TATA-BOX project. }\end{array}$ \\
\hline
\end{tabular}


Table 1 (continued)

\begin{tabular}{|c|c|c|c|}
\hline & Goals & $\begin{array}{l}\text { Inputs presented by } \\
\text { the ergonomist }\end{array}$ & Participatory exercises \\
\hline $\begin{array}{l}\text { Meeting } 3- \\
\text { May } 15 \\
\text { Feedback on } \\
\text { methodology } \\
\text { seminar }\end{array}$ & $\begin{array}{l}\text { Show important moments } \\
\text { of the seminar on } \\
\text { methodology (during } \\
\text { which the organisation of } \\
\text { the project was rebuilt). } \\
\text { Ask about these } \\
\text { moments. } \\
\text { Consider these moments } \\
\text { in different ways. } \\
\text { On the basis of this } \\
\text { feedback, ask about the } \\
\text { evolutionary, adaptive } \\
\text { and collective } \\
\text { characteristics of the } \\
\text { project. }\end{array}$ & $\begin{array}{l}\text { Analysis of the } \\
\text { methodological } \\
\text { seminar }\end{array}$ & $\begin{array}{l}\text { Rethink the } \\
\text { methodological seminar } \\
\text { Instructions: Please think } \\
\text { about how you could do } \\
\text { otherwise if the seminar } \\
\text { methodology had to be } \\
\text { reorganised, for each key } \\
\text { situation of the } \\
\text { methodological seminar. } \\
\text { Material: Post-it notes }\end{array}$ \\
\hline $\begin{array}{l}\text { Meeting } \\
4 \text { - June } 15 \\
\text { Debriefing }\end{array}$ & $\begin{array}{l}\text { Have a return on the } \\
\text { reflective intervention by } \\
\text { the project leaders. } \\
\text { Examine the current } \\
\text { organisation of the } \\
\text { project. }\end{array}$ & $\begin{array}{l}\text { Analysis of all the } \\
\text { meetings of the } \\
\text { intervention }\end{array}$ & $\begin{array}{l}\text { "Build a common } \\
\text { representation of the } \\
\text { organisation of the } \\
\text { project" } \\
\text { Instructions: Please } \\
\text { reconstruct the current } \\
\text { organisation of the } \\
\text { TATA-BOX project by using } \\
\text { labels with the names of the } \\
\text { workgroups and arrows. } \\
\text { Materials: Arrows and labels } \\
\text { with the names of the } \\
\text { different project workgroups }\end{array}$ \\
\hline
\end{tabular}

Table 2 Elements of the coding scheme of reflective activity (Adapted from Chizallet 2015)

\begin{tabular}{l|l}
\hline Places & Activity \\
\hline Withdrawal & A participant avoids a problem or does not answer \\
\hline Testimony & $\begin{array}{l}\text { A participant clarifies or explains his/her view on the basis } \\
\text { of an experience }\end{array}$ \\
\hline Clarification & A participant asks for details/explanations \\
\hline Questioning & A participant outlines a difficulty \\
\hline Proposal & A participant imagines another way to do something \\
\hline
\end{tabular}

\section{Characterising the Reflective Activity}

For Meeting 4: "Feedback on project management and reflective intervention", the three previous meetings were analysed as part of the reflective intervention. All these meetings had been recorded and transcribed. Table 2 presents the coding scheme defined to reveal reflective activity in interaction (Jorro 2005; Chizallet 2015). In this scheme, the reflective activities were classified from the least reflective (withdrawal) to the most reflective ones (proposal). 


\section{Results}

In this section we show three types of results. First, we provide information on the RG's diagnosis of the project management at the beginning of its intervention. This diagnosis produced questions and assumptions that were debated with the project leaders to build the following intervention. Second, we browsed through the results of the four meetings organised with the project leaders. Finally, we discussed the efficiency of the reflective intervention by following the development of traces of reflectivity throughout the intervention.

\section{Diagnosis of the Project Management}

\section{From a Structured to an Adhocratic Project?}

During our first interviews, the project leaders regularly used five adjectives to characterise the project: "participatory, collective, evolutionary, adaptive and adhocratic" (Chizallet 2015).

In the diagnosis they tried to collect information to understand how these characteristics emerged. The various interviews helped us to trace the history of the project: (1) from the emergence of a first intention of the project, (2) through the design of its first version and (3) a redesign of the project.

(1) The intention of the project initially emerged with the question of "How to support an AET?", raised by a team leader who envisaged an adhocratic and participative project emerging from the team. It was then taken up by three other researchers (an economist and two agronomists). Faced with the complexity of the AET concept, they decided to spend time on the conceptual framework that would help to define and support an AET. This brought together different disciplines, theoretical frameworks, and views of agroecology and of transition and research postures. There have been many debates, mainly on how to represent local agriculture and think the transition dynamically. This complexity within the project was discussed at length and the construction phase of the project was long. It resulted in a conceptual framework and a five-step methodology that structures the TATA-BOX project.

(2) A proposal for the TATA-BOX project was then drafted specifically to obtain funding from the French National Research Agency, and therefore did not correspond to the project that the researchers had in mind. For instance, initially there was not supposed to be a project manager, as the project leaders wanted an adhocracy (i.e. organic governance), but the normative frameworks of the ANR did not allow that. The director of the unit consequently took the lead with two other people: an agronomist from the small initial group and a full-time engineer on the project. This leading trio kept its effectiveness in the organisation of the project. To stick to the ANR requirements, the project proposal submitted to the ANR was also divided into five work packages, although the leaders assumed that this organisation would be modified by the project researchers themselves, with a view to building an iterative and more collective project. 
(3) To help the project researchers to appropriate the newly-funded project and to reorganise the project collectively, the project leaders decided to begin the project with several seminars dedicated to first contact and knowledge sharing. These seminars were built to allow the researchers to collectively take ownership of the project, agree on what the project was, what the field was, and discuss misunderstandings. A kick-off meeting marked the launch of the project in January 2014. All the researchers presented their research activities so that each of them could locate themselves in relation to one another and to the project. This allowed the researchers to build bridges between their various research activities. In addition, the seminar highlighted the existence of several representations of agroecology. A field seminar was organised 4 months later, in Aveyron, to discover the terrain and discuss the concept of agroecology. This seminar also allowed the researchers to meet some of the stakeholders. From there, it was decided to re-organise the TATA-BOX project. Following their idea of rebuilding of more polycentric project after its acceptance by the ANR, the project leaders organised a "methodological seminar" in September to reorganise the project work. Seven groups emerged from this seminar. There were about ten researchers in each group, some of whom were present in several groups, and of whom had joined voluntarily. The groups were not supposed to be fixed, but rather to be reorganised during the course of the project.

\section{Identification of Project Management Issues}

Apart from setting out the history of the project design, this diagnosis allowed us to highlight various issues that might be improved to enhance the functioning of the project. In this chapter, we detail only detail those three that relate to the project management.

Firstly, our diagnosis underlined a first project management issue related to the objectives of the project. It revealed that there was a lack of synchronisation among the participants, with regard these objectives. The project leaders shared the same idea that the project was not intended to support the AET but rather to design a methodology to support the actors in building their own AET. However, when asked about the objectives of the project, the participants were not so clear. There seemed to be some confusion and discrepancy between them, mainly concerning the researchers' intention to support the territorial AET or not. We thus assumed that, after 9 months and in spite of the different seminars, not all project researchers had managed to share a common vision of the project. This is a well-known difficulty of project management. Many studies on design processes have revealed that the objectives of a project are often "ill-defined" and that a synchronisation activity between the project participants is deeply needed. Several studies have focused on this highly important but time-consuming activity in design meetings (e.g. Falzon and Darses 1996; Détienne 2006; Visser 2009).

Secondly, following the same idea of a lack of synchronisation, we characterised a second project management issue dealing with the conceptual and methodological framework of the project. We have explained above that after extensive debate about 
what an AET could be and how to analyse and support it, a framework was proposed in Duru et al. (2014, 2015), distinguishing five steps for designing an AET. The interviews showed that while some researchers had taken up this framework, others had more difficulties with it. For some of them, the framework was too different from their own conceptual and methodological backgrounds. Others pointed out that it seemed contradictory to claim that the project needed to be adaptive and evolutionary and, at the same time, to set quite a rigid framework from the outset. There was thus a lack of synchronisation about the conceptual and methodological framework of the project. Note nevertheless that the project leaders claimed not to set up definite concepts. Acknowledging the complexity of the subject, they thought that some vagueness was needed to allow the participants to work together. As soon as the framework would be too definite, it would exclude some participants. There was then a balance to find between too much and too little framing.

From these two elements of difficulty, we built two assumptions. Firstly we assumed that the fact that the project had been built by several little collectives successively did not favour its quick take up by all the project researchers. Secondly, we assumed that the various transformations of the project were not sufficiently thought out and that not all project researchers adhered to these transformations. Some of them did not adhere to the transformation from the initial project into an ANR normative project. Others had difficulties with the idea of detaching themselves from the normative aspect of the project to re-create a new dynamics for the project. As a result, a two-speed project was appearing: one with the participants who applied the methodological framework, and the other with the researchers who fed the project but outside of its main dynamics. This may be considered as a success - albeit partial - with regard to the project goals: the project leaders had indeed succeeded in creating a collaborative dynamics among some researchers who applied the methodological framework, whereas research projects often consist in gathering competencies without building a collaborative dynamic.

Finally, a last project management issue appeared. From the diagnosis, it appeared that the three project leaders had significant decision-making power in the project, which was partly contradictory with their own will of building a participatory, adhocratic project. Moreover, the interviews showed that the distribution of roles between these researchers was not clearly formalised and that the roles each of them assumed sometimes impinged on the role of their colleagues.

On the basis of this first diagnosis outlining an on-going redesign process of the project and these three project management issues, we began our work with the three project leaders. Our common objective was to build a reflective intervention in order to help the project leaders to redesign the project on an on-going basis by following their participatory and adhocratic intention, and in order to deal with the project management issues identified. In addition, we opportunistically adapted the intervention to the demands expressed by the project leaders (e.g. Meeting 2, to be equipped with conceptual issues regarding project management from an ergonomic point of view), and to the events of the project (e.g. Meeting 3, feedback on a seminar conducted during the intervention). We now first review the dynamic aspects of the intervention, and then consider its efficiency in relation to the enhancement of reflectivity. 


\section{Dynamics of the Reflective Intervention}

The first meeting was used to build a common understanding of the project management and its stakes. Starting with our external understanding of the project, developed during the diagnosis, we intended to discuss and clarify this common understanding. We thus presented the main results of our diagnosis to the project leaders: the way we had understood the building of the project over time, the difficulties the researchers of the project had to define the precise objectives of the project and their current role in the transformation of the agricultural practices in the field, and their questions about the structuring of the project and the need to organise the work of the three project leaders. All these points were discussed with the project leaders. We then organised a participatory exercise to support the project leaders' thinking about their respective roles. This enabled them to clarify these roles, as shown in Fig. 2.

At the end of this first meeting, the project leaders asked for more information about the conceptual frameworks that we used to analyse their management. The second meeting was therefore intended to open up possibilities for the project leaders by giving some bibliographic elements about conceptual frameworks in relation to design, project management and participation. A focus was put on the notion of "adhocracy" which was often used by the project leaders. A discussion was then initiated on the transposition of these frameworks to the TATA-BOX project. This discus-

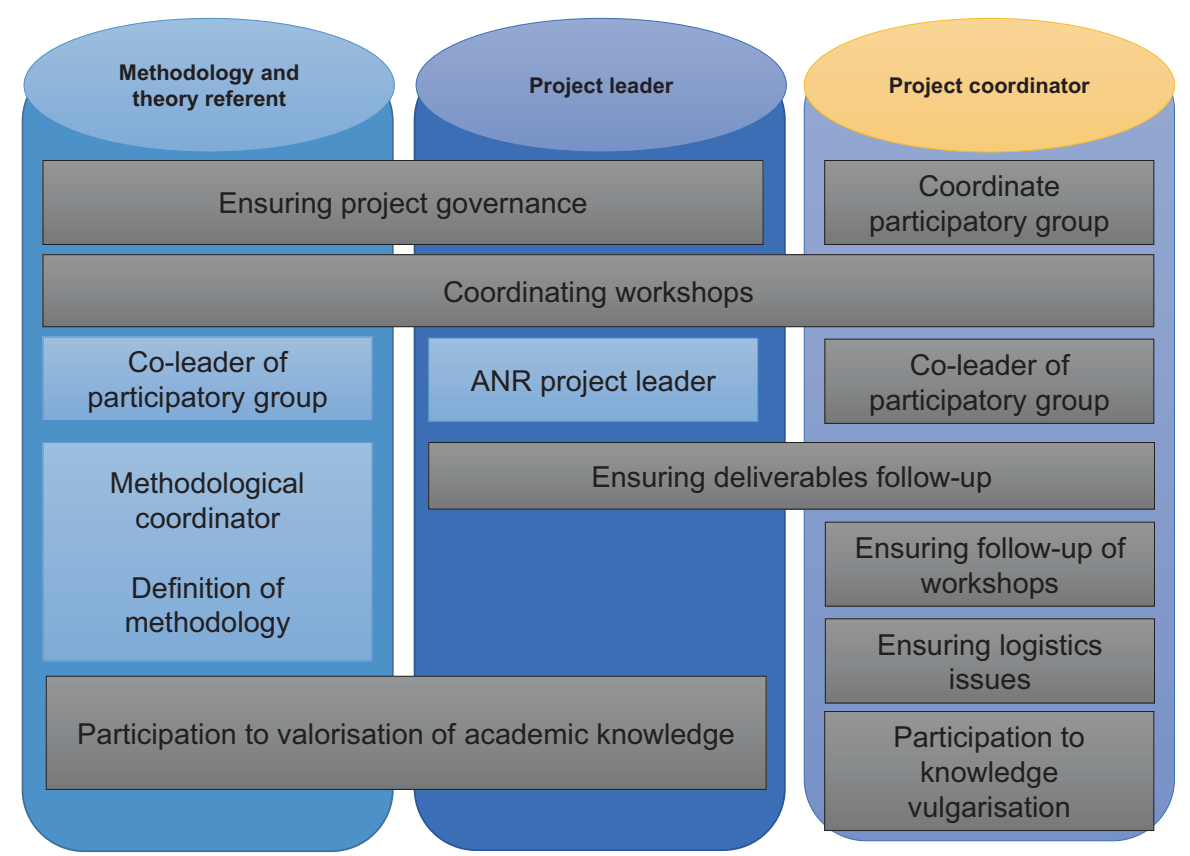

Fig. 2 Representation of project leaders' roles built by themselves 
sion showed that, through the use of adjectives to qualify the project, like "participatory, evolutionary, adhocratic, adaptive and collective", the project leaders wanted to find a way to involve all the project participants. Their intention was to generate a dynamic, constantly re-designed that incorporated learning generated through its implementation. So what they wanted was responsiveness, collegiality and shared management. We argued that this type of management may be supported by a continuous reflective appraisal. As the project leaders still had difficulties in imagining how to implement such ideas, it was decided that we would demonstrate the use of feedback to feed reflection about their management and ways to make it evolve. We then decided to provide some feedback about the methodological seminar. This feedback was based on interviews with some of the participants and an analysis of the audio recording of the seminar, between the second and the third meeting.

The third meeting provided feedback on the "methodological seminar" of the project that was key to organising its management. This feedback was meant to allow the project managers to imagine how they could have run this seminar differently. Based on the ergonomist's analysis of the seminar, the project leaders could experience the gap between their initial intention, the actual execution of the meeting, and the participants' feedback. The seminar was structured around the three main topics planned by the project leaders: (1) positioning the respective research activity of each researcher; (2) building work groups of researchers; and (3) beginning to work in groups. The interviewed participants evaluated the interactions occurring during the first part as the most useful ones, for they helps them to develop a better understanding of each participant's objectives and tasks. Discussions and interactions occurring in the following two steps likewise contributed to the construction of a common ground between participants. The participants of the seminar however considered the structuring and management that came from these steps (constitution of groups and management of these groups) to be "fuzzy". There was some misunderstanding about the way the groups were constituted and some ambiguity in their management. This feedback was intended: (1) to be a probe to stimulate the design of alternative ways of organising methodological seminars in the future; and (2) to critically examine the actual participatory and adhocratic way of managing the project. For instance, the methodological seminar led to the constitution of seven groups of researchers, but the potential evolution of these groups was not discussed, nor were the criteria used to adapt the project en route. The project leaders were asked to imagine solutions to deal with these project management issues.

The fourth meeting was intended to be a debriefing on the reflective intervention proposed and a critical examination of the actual organisation of the project. The ergonomist presented some results regarding reflective activities performed or not by the project leaders, and questioned the actual organisation of the project on the basis of a synthesis of previous meetings and participants' contribution to the project feedback. It was an opportunity once again to go over the various elements discussed during the different meetings: the need for synchronisation, the functioning of the three project leaders, the importance of feedback to inform an adaptive project, and so on. This meeting was also an opportunity to question the project leaders about the intervention itself: what they had learned about managing the project, 
what they would have done differently, what they would do in the future about the organisation of the project, and what kinds of tools they would use to do so. We discuss these elements in the following section by combining the project leaders' comments during this fourth meeting with our own analysis of the efficiency of our intervention.

\section{Efficiency of the Reflective Intervention}

The objective of our intervention was to enhance the reflective postures of the project leaders regarding their project management activity. To evaluate in which way our methodology was successful in reaching this objective, we analysed the actual activities performed by the project leaders in the three meetings we organised, using the coding scheme presented in Table 2. Various analyses were carried out: we analysed the weight of the different degrees of reflectivity for each meeting and over time; we compared the profiles of each project leader and their evolution over time; we also worked on the links between the position of the ergonomist (what she does or asks when she intervenes) and the reflectivity it provokes. Finally, we collected the opinions of the three participants during Meeting 4.

To illustrate the analysis carried out from the transcriptions of the different meetings and the coding of the degrees of reflectivity, we discuss the comparison of the participants' postures between Meetings 1 and 3. The results of this analysis were consistent with several of what Mollo and Nascimento have called "Golden Rules of reflective practice". These rules do not precisely describe how to implement reflectivity but they draw the boundaries within which reflective methods "may be deemed constructive" (Mollo and Nascimento 2014). Four of them are defined as follows: "focusing on the real aspects of work activity"; "a regular and perennial collective"; "the joint elaboration and evaluation of solutions"; and "the involvement and commitment of the hierarchy" (Mollo and Nascimento 2014). The first two have an interesting illustration in the comparison of the participants' postures between Meetings 1 and 3. Figures 3 and 4 represent the distribution of postures in these meetings and show that the project leaders were actually in reflective postures in the sense of Jorro (2005) but to differing degrees. In both cases, "testimony" and "clarification" were the most important postures. Interestingly, the "proposal" posture - the highest degree of reflectivity - was more important in Meeting 3: "Feedback on methodological seminar", and no attitude of withdrawal - the lowest degree of reflectivity - was observed in this meeting.

There is thus a global improvement of the reflectivity from Meeting 1 to Meeting 3. Various factors explain these differences.

- We can assume that there was more trust between the participants of the reflectivity meetings as the process progressed, and that the project leaders had a better understanding of what the RG was trying to build with them. This could be linked with the rule of having a "regular and perennial collective". 


\section{Meeting 1 - Construction of a common ground}

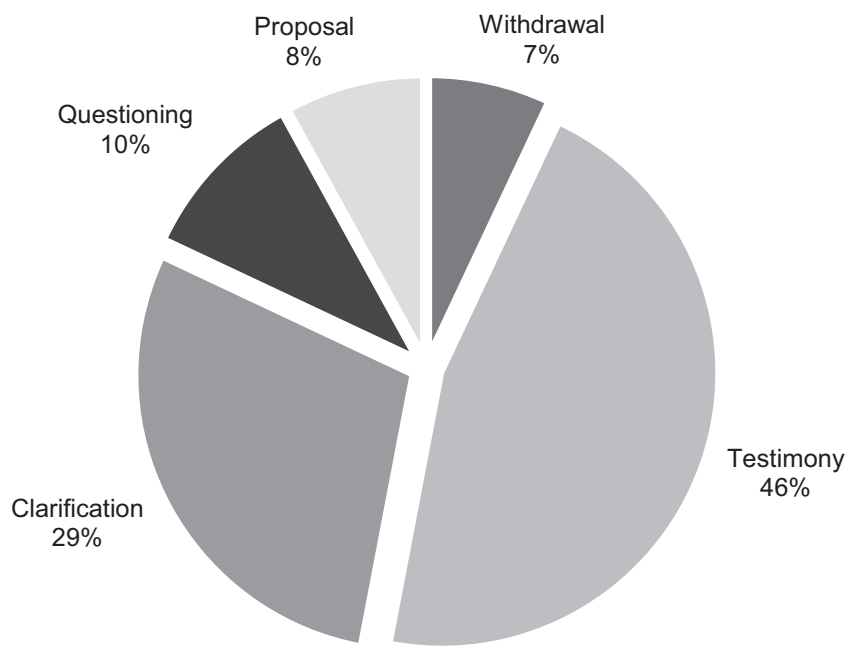

Fig. 3 Postures of participants in meeting 1 (\% of contributions of the three project leaders)

\section{Meeting 3 - Feedback on methodological seminar}

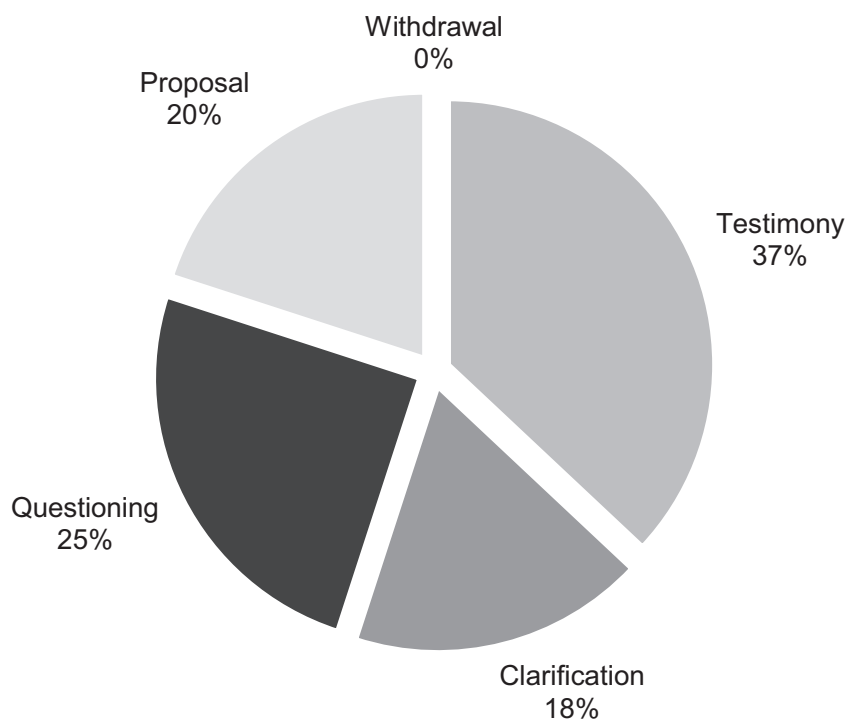

Fig. 4 Postures of participants in meeting 3 (\% of contributions of the three project leaders) 
- More discussion around "proposals" can also be linked with the objective of Meeting 3, which was to support the project leaders in imagining alternative ways of running methodological seminars in the future. Actually, the ergonomists' inputs were different. Meeting 1 was based on their diagnosis of the project. This meeting had been defined as an opportunity to clarify this diagnosis, which was questionable and encompassed the entire project. It was therefore logical that the project leaders were more in a posture of testifying and specifying, in order to feed the project diagnosis and foster mutual understanding with the RG.

- Finally, Meeting 3 was built on feedback from an extremely important seminar for the organisation of the project. This feedback was by the ergonomist, based on the minutes of the seminar and interviews with the participants. It was thus less questionable as it was based on actual observations, activity analysis and testimonies of their colleagues. This feedback thus contributed elements to help the project leaders in building a factual opinion about the methodological seminar. Figure 4 suggests that this is helpful to generate ideas to "do otherwise". This may outline the importance of grounding the proposition of alternatives ways of managing the project in discussions based on actual past experiences. This is in line with the Golden Rule "focusing on the real aspects of work activity" of reflective practice: "The object of reflective practices must be work activity in the real world. To avoid 'drifting' towards a general discussion about work and life in the organisation, this practice may be supported by films, pictures or accounts of situations that emphasise the real conditions in which the work is carried out" (Mollo and Nascimento 2014): 215-216).

Ultimately, this reflective intervention was an interesting opportunity for our RG as it allowed us to test different methods and tools to support a reflective process while trying to base our intervention, as much as possible, on the actual work and activity, in line with the principles of Activity-Centred Ergonomics. But what was the efficiency of our intervention from the participants' point of view? From the discussions in Meeting 4, we can see that their opinions were mixed. They appreciated having an opportunity to discuss the management of a project that was not easy for them. The fact of having secured monthly meetings on that subject was considered to be very positive as they would not have taken this time otherwise. They also explained that these meetings forced them to express some difficulties: "you have identified a number of points, dysfunctions, problems, points to improve, and for that you guided us in the discussions, or you have even implemented workshops to formalise things that were very implicit in our mode of operation (...), I often had the impression that you led us to explain the implicit" (one of the project leaders). However the project leaders expressed a lack of effective help for managing the project, as the following very interesting discussion in Meeting 4 illustrates:

- I have the impression that we've taken dedicated time for discussions between us and that you've equipped us to discuss matters between us, and you've supported us in discussions. This is always very positive and constructive, but I didn't feel that I was adequately equipped with tools to lead the project. (project leader). 
- I'm surprised that you say there are no tools, especially methodological. (...) We used many different methods to animate this reflective device and our idea was that these methods should also help you to continue to animate the work of organising the project with other researchers. (ergonomist)

- I didn't think at all that the methods you used to get us to discuss and to be reflective about the project were potentially methods to animate the project. And it seems that you thought we were aware that the methods you put on the table to animate these meetings were potentially methods that could have been used to animate the project (project leader).

This interaction suggests that our second objective of showing the project leaders how they could, on their own, build some reflective areas for the project people in order to support their intention of managing their project in a "participatory, collective, evolutionary, adaptive and adhocratic" way was largely missed. Whereas we had the impression of having expressed this objective clearly during the Proposal Meeting and through the participatory exercises, this was obviously not the case. As such, even though our intervention was an interesting step for the project leaders, its continuity was compromised.

\section{Discussions and Perspectives}

The TATA-BOX project leaders definitely had a challenging task of managing a research project in a "participatory, collective, evolutionary, adaptive and adhocratic" way - an intention they had expressed to be consistent with their understanding of transition processes in agriculture. A crucial question is how to manage a project to make it innovative. In fact, traditional project management has been criticised extensively when it comes to innovative design that "render[s] its hypothesis (i.e., the ability to identify a clear objective, to plan the work, etc.) irrelevant" (Lenfle et al. 2016). And the particularities of the transition processes in the agricultural world show that these hypotheses are currently largely irrelevant. Acknowledging this, the TATA-BOX project intended to have an innovative management by involving all the researchers of the project in the decision process and by being adaptive. Although several studies have advocated the use of adaptive and iterative modes of design management in agriculture, they are mostly conceptual (Le Gal et al. 2011; Meynard et al. 2012) and fall short of proposing methodological tools to support action. Or when they do describe how to implement this type of management (Giller et al. 2011), they are most often focused on only one iteration (Dogliotti et al. 2014; Falconnier et al. 2017), which raises the question of the management of such processes over the long run and the ways to support it. TATA-BOX was precisely a project intended to address such questions. But our diagnosis of the project management after just 1 year highlighted the fact that the participants had not sufficiently discussed the project objectives and the conceptual and methodological framework together. In terms of management, our diagnosis showed a discrepancy between the intention of the project leaders and their actual possibilities. Confronted with the need not only to produce deliverables and to report to the ANR, 
but also to manage a project whose objectives and framework were not totally clear for every participant, they had to take a lead in a way that was at odds with their intended adhocracy. The reflective intervention we built with them over 6 months was intended to give them an opportunity to discuss these discrepancies and how to solve them.

As such, the reflective intervention proposed was one of the first attempts, as far as we know, to implement Activity-Centred Ergonomics proposals around the development of reflective intervention, which is part of a more general project of conceptualisation and operationalisation of enabling intervention (Barcellini 2015, 2017 for a synthesis, and Arnoud and Perez Toralla 2017). Although our results show that our intervention succeeded in provoking reflectivity among the project leaders, it partly failed to enable them to manage the project further. This reveals that methods supporting reflective activity per se are not sufficient to support the development of a redesign activity in project management. It would have been necessary to couple them with methods explicitly targeting a more projective activity (e.g. Chizallet et al. 2018) submitted), that is, an activity dedicated to re-designing the activity at stake, using tools such as organisational simulation (Barcellini and Van Belleghem 2014). In this sense, the workshops organised would have benefitted from more applied exercises to help the project leaders in addressing very real difficulties of project management. It may have helped to transform this reflectivity into a more projective activity. In other words, our intervention supported the constructive activity of the project leaders but not through to the end. If we consider that our intervention was expected to support the design of a project management, we can see that it supported the first typical steps of a design process, that is, synchronisation and grounding between the project leaders regarding the actual situation and the goals to reach, but that it stopped before totally supporting the generative step of design processes. This was attempted with the exercises that concluded each meeting, but they were obviously not linked enough to the actual management issues of the project leaders. This may suggest that moments of reflective and projective activities should have been distinguished over time in a longer intervention. Moreover, due to the financial constraints of the funding programme, the RG was provided with funding for only two 6-month interns. Looking back, this funding was largely insufficient compared with the ambition of the RG. An ergonomist recruited specifically to monitor the project leaders over the long run would have been necessary to support them throughout the project and to carry out additional analyses of the researchers' actual work in the project and with the stakeholders (e.g. Chap. 11). This would have been more in line with the objective.

As a last point of discussion, we would like to come back to the tension we evoked between the idea of clarifying the objectives and framework of the project, and the idea of leaving them vague enough so that participants are not excluded. We have the feeling that these two approaches are not necessarily mutually exclusive. If openness is needed for complex concepts, to build certain interdisciplinary work, this does not mean that such openness should be experienced as ambiguity. It would be better to collectively acknowledge it so that it becomes a resource for the collective and not a source of confusion. This is in line with the idea of integrating uncer- 
tainty into the management of "exploratory" projects rather than managing to progressively reduce uncertainties (e.g. Lenfle 2016). Our proposition to use reflectivity to manage the project precisely aimed at making this uncertainty visible, in order to make it manageable. The reflective tools did allow for a representation of actual actions performed by participants when confronted with actual situations, which made it possible for the project leaders and the project researchers to adapt, correct, and reorient their action. In that sense, the reflectivity was used to feed the adaptive character of the project. More broadly, the points that we discussed with regard to the design of the TATA-BOX project management are also significant for other design processes in agriculture. What was at stake in the TATA-BOX management was the project researchers' ability to build by themselves an organisation that would be efficient and adaptive. There was then a challenge to articulate a design direction or intention (that is to say, an intention for the future, a goal that directs the design project) to a continuous adaptation of the actual situation. Looking at the design processes of agricultural systems, we can find the same stake and the same challenge (Prost et al. 2018). Given the complexity and uncertainties of designing agricultural systems, farmers should be reconsidered as designers of their own production systems. The role of research agronomists in the design processes is consequently being called into question: their role is seen more as a support for farmers' design activity than as a substitute for it. These researchers are therefore confronted with the same challenge as the project leaders of TATA-BOX: they have to find how to support the farmers in the design of their own agricultural systems. To do so, they can feed a design direction by helping the farmers to be innovative. At the same time, acknowledging the nature of design processes, they also need to assess and show the effects of the design solutions implemented in actual situations, in order to allow the farmers to iteratively adapt their design processes. This would require identification of the appropriate tools.

\section{References}

Arnoud J, Perez Toralla M-S (2017) L'intervention capacitante: quels enjeux pour la pratique de l'ergonome? Activités. https://doi.org/10.4000/activites.3042

Barcellini F (2015) Développer des interventions capacitantes en conduite du changement. Comprendre le travail collectif de conception, agir sur la conception collective du travail. Université de Bordeaux

Barcellini F (2017) Intervention Ergonomique Capacitante: bilan des connaissances actuelles et perspectives de développement. Activités. https://doi.org/10.4000/activites.3041

Barcellini F, Van Belleghem L (2014) Organizational simulation: issues for ergonomics and for teaching of ergonomics' action. In: ODAM 2014 (11st Human factors in organizational design and management conference)

Barcellini F, Van Belleghem L, Daniellou F (2014) Design projects as opportunities for the development of activities. In: Falzon P (ed) Constructive ergonomics. CRC Press, Boca Raton, London, New York, pp 150-163

Béguin P (2003) Design as a mutual learning process between users and designers. Interact Comput 15:709-730 
Chaubet $\mathrm{P}$ (2010) Saisir la réflexion pour mieux former à une pratique réflexive: d'un modèle théorique à son opérationnalisation. Éducation Francoph 38:60-77

Chizallet M (2015) Conduire l'activité réflexive pour soutenir la conduite de projet: une étude exploratoire. Master Sciences Humaines et Sociales, Mention CNAM, Travail et Développement, Spécialité Ergonomie

Chizallet M, Barcellini F, Prost L (2018) Supporting farmers' management of change towards agroecological practices by focusing on their work: a contribution of ergonomics. Cah Agric 27:35005. https://doi.org/10.1051/cagri/2018023

Daniellou F (1992) Le statut de la pratique et des connaissances dans l'intervention ergonomique de conception. 1992. Université de Toulouse-Le Mirail

Daniellou F, Rabardel P (2005) Activity-oriented approaches to ergonomics: some traditions and communities. Theor Issues Ergon Sci 6:353-357

Détienne F (2006) Collaborative design: managing task interdependencies and multiple perspectives. Interact Comput 18:1-20. https://doi.org/10.1016/j.intcom.2005.05.001

Dogliotti S, Rodríguez D, López-Ridaura S et al (2014) Designing sustainable agricultural production systems for a changing world: methods and applications. Agric Syst 126:1-2. https://doi. org/10.1016/j.agsy.2014.02.003

Duru M, Fares M, Therond O (2014) A conceptual framework for thinking now (and organising tomorrow) the agroecological transition at the level of the territory. Cah Agric 23:84-95. https://doi.org/10.1684/agr.2014.0691

Duru M, Therond O, Fares M (2015) Designing agroecological transitions; a review. Agron Sustain Dev. https://doi.org/10.1007/s13593-015-0318-x

Falconnier GN, Descheemaeker K, Van Mourik TA et al (2017) Co-learning cycles to support the design of innovative farm systems in southern Mali. Eur J Agron 89:61-74. https://doi. org/10.1016/j.eja.2017.06.008

Falzon P, Darses F (1996) La conception collective: une approche de l'ergonomie cognitive. Coopération et conception, Octarès, 123-135

Giller KE, Tittonell P, Rufino MC et al (2011) Communicating complexity: integrated assessment of trade-offs concerning soil fertility management within African farming systems to support innovation and development. Agric Syst 104:191-203. https://doi.org/10.1016/j. agsy.2010.07.002

Guérin F, Laville A, Daniellou F, et al (2006) Comprendre le travail pour le transformer, la pratique de l'ergonomie. Lyon

Holling CS (1978) Adaptive environmental assessment and management. John Wiley \& Sons, London

Jorro A (2005) Réflexivité et auto-évaluation dans les pratiques enseignantes. Mes évaluation en éducation 27:33-47

Le Gal PY, Dugué P, Faure G, Novak S (2011) How does research address the design of innovative agricultural production systems at the farm level? A review. Agric Syst 104:714-728. https:// doi.org/10.1016/j.agsy.2011.07.007

Le Goff JL (2014) La réflexivité dans les dispositifs d'accompagnement: implication, engagement ou injonction? \& Interrog? 11

Lenfle S (2008) Exploration and project management. Int J Proj Manag 26:469-478

Lenfle S (2016) Floating in space? On the strangeness of exploratory projects. Proj Manag J 47:47-61. https://doi.org/10.1002/pmj.21584

Lenfle S, Le Masson P, Weil B (2016) When project management meets design theory: revisiting the Manhattan and Polaris projects to characterize 'radical innovation' and its managerial implications. Creat Innov Manag 25:378-395. https://doi.org/10.1111/caim.12164

Meynard JM, Dedieu B, Bos AP (2012a) Re-design and co-design of farming systems: an overview of methods and practices. In: Darnhofer I, Gibbon D, Dedieu B (eds) Farming systems research into the twenty-first century: the new dynamic. Springer, Dordrecht, pp 407-431

Mollo V, Nascimento A (2014) Reflective practices and the development of individuals, collectives and organizations. In: Falzon FD-P (ed) Constructive ergonomics, pp 223-238 
Perrenoud P (2001) Développer la pratique réflexive dans le métier d'enseignant

Petit J, Querelle L, Daniellou F (2007) Quelles données pour la recherche sur la pratique de l'ergonome? Trav Hum 70:391-411

Prost L, Reau R, Paravano L et al (2018) Designing agricultural systems from invention to implementation: the contribution of agronomy. Lessons from a case study. Agric Syst 164:122-132

Samurçay R, Rabardel P (2004) Recherches en didactique professionnelle, Octarès. Toulouse

Schön D (1983) The reflective practitioner: how practitioners think in action. Basic Books, New York

Teiger C, Falzon P (1995) Construire l'activité. Performances Hum Tech Hors Série 34-40

Vinck D (2009) De l'objet intermédiaire à l'objet-frontière, Vers la prise en compte du travail d'équipement. Rev. d'anthropologie des connaissances 3:51-72

Vinck D (2011) Taking intermediary objects and equipping work into account in the study of engineering practices. Eng Stud 3:25-44. https://doi.org/10.1080/19378629.2010.547989

Visser W (2009) Design: one, but in different forms. Des Stud 30:187-223. https://doi. org/10.1016/j.destud.2008.11.004

Walters CJ (1986) Adaptive management of renewable resources. MacMillan Pub Co, New York

Open Access This chapter is licensed under the terms of the Creative Commons Attribution 4.0 International License (http://creativecommons.org/licenses/by/4.0/), which permits use, sharing, adaptation, distribution and reproduction in any medium or format, as long as you give appropriate credit to the original author(s) and the source, provide a link to the Creative Commons licence and indicate if changes were made.

The images or other third party material in this chapter are included in the chapter's Creative Commons licence, unless indicated otherwise in a credit line to the material. If material is not included in the chapter's Creative Commons licence and your intended use is not permitted by statutory regulation or exceeds the permitted use, you will need to obtain permission directly from the copyright holder.

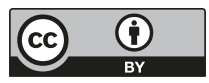

